Rok XV (2020) | 1 (29) | S. 47-58

https://doi.org/10.12797/LV.15.2020.29.03

Bernadetta Ciesek-Ślizowska •

Uniwersytet Śląski, Katowice

bernadetta.ciesek@us.edu.pl

Beata Duda (1)

Uniwersytet Śląski, Katowice

beata.duda@us.edu.pl
Katarzyna Sujkowska-Sobisz (1)

Uniwersytet Śląski, Katowice

katarzyna.sujkowska-sobisz@us.edu.pl

\title{
O (NIE)WIDOCZNOŚCI PROWADZĄCEGO SPOTKANIE ZE ŚWIADKIEM HISTORII - WSTĘPNA TYPOLOGIA RÓL INICJUJĄCYCH WYWIADY NARRACYJNE ${ }^{1}$
}

Słowa klucze: role nadawczo-odbiorcze, rozmowa, narracja, historia mówiona, pamięć Keywords: sender and recipient roles, conversation, narration, oral history, memory

Wyrazem zainteresowania autentycznością we współczesnej przestrzeni komunikacyjnej jest zwrot ku oralności (por. Ong 1992; Havelock 2006), w wyniku którego nobilitowane są bezpośrednie, nierzadko nacechowane potocznością akty komunikacji odzwierciedlające indywidualne punkty widzenia. Jednym z przykładów wykorzystywania potencjału żywej mowy w kształtowaniu wiedzy i ustalaniu społecznych znaczeń są działania w ramach nurtu tzw. historii mówionej (oral history). Pod tym pojęciem kryją się zarówno metody badawcze, dzięki którym możliwe jest rejestrowanie wspomnień „świadków historii”, jak i specyficzny kierunek badań skoncentrowany wokół dziejów „zwykłych ludzi” (Stolarz 2012: 103). Tego typu badania mają charakter interdyscyplinarny - pamięć jednostek staje się przedmiotem analiz przedstawicieli wielu dziedzin i dyscyplin nauki. Wśród nich dominują historycy, socjologowie i antropolodzy, którzy w zależności od przyjętej perspektywy badawczej

1 Wkład poszczególnych autorek w powstanie artykułu jest równy i wynosi po 33,3\%. Koncepcja oraz wykonanie są w pełni współautorskie. 
nieco inaczej profilują obiekt dociekań. Dla historyka istotna jest treść wspomnień, zwłaszcza ich faktograficzny wymiar. Badacze z kręgu nauk społecznych koncentrują się na podmiotowych i interakcyjnych aspektach procesu „odświeżania” pamięci.

Jak dowodzą najnowsze ustalenia (por. Pamięć), pamięć i jej tekstowe aktualizacje w relacjach świadków historii mogą stać się przedmiotem naukowego namysłu także lingwistów. W artykule chcemy zatem naświetlić możliwości lingwistycznej analizy niezwykle zróżnicowanego materiału, jakim są teksty powstałe dzięki wykorzystaniu narzędzi właściwych historii mówionej. W centrum zainteresowań tego nurtu usytuowana jest pamięć będąca wyrazem indywidualnego spojrzenia na przeszłość, jednakże mocno zapośredniczonego w tradycji i kulturze. Stąd też jednym z postulatów badaczy historii mówionej jest „przekształcenie indywidualnych wspomnień w kulturową narrację, dzięki czemu będzie możliwe lepsze rozumienie przeszłości" (Grele 1996: 48). W opozycji do pamięci dotychczas sytuowana była historia - pozbawiona elementu podmiotowego w postaci jednostkowych punktów widzenia, a zatem odhumanizowana oraz utożsamiana z imperalizmem i państwem (Pamięć, etyka: 16). Współcześnie jednak granice między pamięcią a historią są zacierane (Pomian 2006: 185), czego dowodem są archiwa historii mówionej włączane do szerszej kategorii archiwów społecznych.

W tego typu przedsięwzięciach tworzone są obszerne i zróżnicowane pod względem zasobów zbiory rozmów ze świadkami historii opracowywane przez historyków, naukowców obywatelskich lub wolontariuszy. Wspomnienia utrwalane są w postaci nagrań, a następnie zazwyczaj transkrybowane i udostępniane szerokiemu gronu odbiorców. W Polsce tworzenie społecznych archiwów historii mówionej rozpoczął Ośrodek KARTA (W1) projektem „Archiwum Wschodnie”, który rozpoczęto w 1987 r., a którego celem była dokumentacja wojennych i powojennych losów Polaków na Wschodzie. Od tego czasu budowaniem archiwów historii mówionej zainteresowały się różne instytucje. Swój udział w tworzeniu tego rodzaju archiwów mają zarówno samorządowe czy państwowe instytucje kultury, jak i organizacje pozarządowe. Fundacja Ośrodka KARTA, podobnie jak krakowska Fundacja Kobieca eFKa (W2) lub Ośrodek „Pogranicze - sztuk, kultur, narodów” w Sejnach (W3) to organizacje tzw. trzeciego sektora, często o bogatej tradycji, niektóre z nich istnieją od prawie 30 lat. $\mathrm{W}$ przypadku archiwów prowadzonych przez te instytucje mamy do czynienia $\mathrm{z}$ archiwami społecznymi sensu stricto, w których walor pozainstytucjonalny, społeczny przypisać możemy nie tylko świadkom historii, ale i osobom, które się z nimi spotykają i z nimi rozmawiają. Archiwa społeczne sensu largo to natomiast te, które prowadzone są przez samorządowe lub państwowe instytucje kultury. Czyli po jednej stronie znajduje się instytucja finansowana $\mathrm{z}$ budżetu państwa, a po drugiej - świadek historii, osoba prywatna, przedstawiciel społeczeństwa. W kontekście takich jednostek warto przywołać przynajmniej Ośrodek „Brama Grodzka - Teatr NN" z Lublina (W4) lub Ośrodek Pamięć i Przyszłość z Wrocławia (W5). 
W dalszej części tekstu zamierzamy poddać oglądowi badawczemu zapisy spotkań ze świadkami historii zamieszone w Archiwum Historii Mówionej (APW1). Jest to miejsce prowadzone przez samorządową instytucję kultury - Muzeum Powstania Warszawskiego - gromadzące około 4000 zarejestrowanych rozmów z uczestnikami wydarzenia $1944 \mathrm{r}$. Relacje świadków powstania warszawskiego gromadzone są od początku istnienia Muzeum, czyli od 2004 r. Spotkania rejestrowane są kamerą wideo, następnie twórcy archiwum dokonują transkrypcji wywiadów, nie ingerując w nie, dzięki temu w finalnym odbiorze osoby zainteresowane zapoznaniem się ze wspomnieniami świadków historii otrzymują zapis, który zachowuje wartość dokumentu.

Dla lingwisty te wypowiedzi stanową nieoceniony materiał badawczy. Po pierwsze dlatego, że dotyczą one ważnego momentu historycznego w kontekście życia narodu. Po drugie, głos zabierają świadkowie socjologicznie różni, są to zarówno kobiety, jak i mężczyźni, osoby w różnym wieku - w trakcie powstania miały nie więcej niż 30 lat, choć jest też sporo osób, które w 1944 r. były kilkuletnimi dziećmi. Inne parametry społeczne świadków historii związane są z ich umocowaniem konspiracyjnym przed powstaniem, a także charakterem udziału w tym wydarzeniu, a mianowicie czynnym jako żołnierz czy biernym jako cywil. Po trzecie, analiza kilkudziesięciu rozmów wyraźnie wskazuje, że istnieje pewien odgórny scenariusz spotkania ze świadkami historii, o którego zrealizowanie musi zadbać prowadzący rozmowę. Treści, które pojawiają się w każdym analizowanym tekście, porządkowane są na podstawie pewnych cezur. Zawsze padają pytania dotyczące życia przed 1 IX 1939 r., kolejny etap wyłuskiwany z całej opowieści to okres od rozpoczęcia wojny do wybuchu powstania. Kluczowa dla każdego spotkania jest data 1 VIII 1944 r., a kolejne to: termin zakończenia udziału w powstaniu w odniesieniu do momentów finalnej kapitulacji i opuszczenia Warszawy przez konkretnego świadka. Ważne dla prowadzącego spotkanie jest także to, co działo się między zakończeniem udziału w powstaniu a końcem wojny. Ostatnim etapem interesującym prowadzącego rozmowę jest czas powojenny, zwłaszcza w kontekście ewentualnych reperkusji związanych z powstańczą przeszłością świadka. Scenariusz ten mógłby przyjąć następującą prezentację ikoniczną dzięki wykorzystaniu osi czasu: 
Wykres 1. Temporalne umocowanie scenariusza rozmowy ze świadkiem historii w Archiwum Historii Mówionej

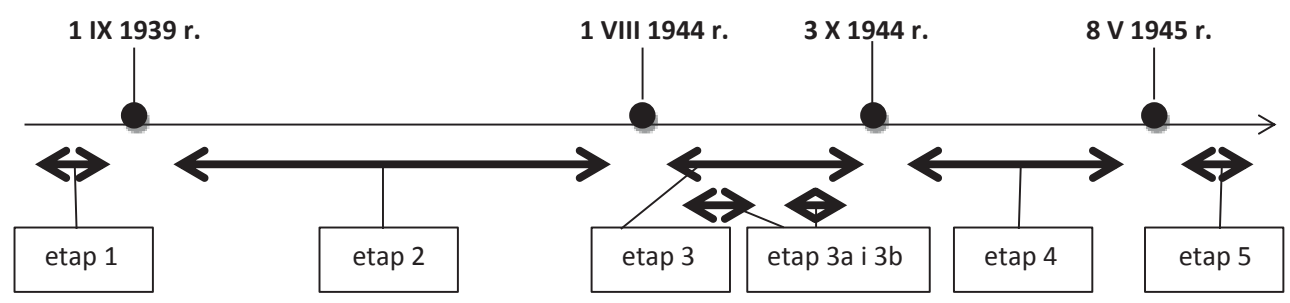

Legenda:

etap 1: czasy przedwojenne

etap 2: od momentu rozpoczęcia wojny do momentu rozpoczęcia powstania

etap 3: od momentu rozpoczęcia powstania do momentu kapitulacji

etap 3a: od momentu rozpoczęcia powstania do momentu indywidualnego zakończenia udziału w powstaniu

etap 3b: od momentu indywidualnego zakończenia udziału w powstaniu do momentu kapitulacji

etap 4: od momentu kapitulacji do zakończenia wojny

etap 5: czasy powojenne

Źródło: opracowanie własne.

Istnieje jeszcze jedna istotna zależność o charakterze temporalnym dotycząca relacji między narodzinami świadka, momentami kluczowymi dla scenariusza a momentem prowadzenia spotkania ze świadkiem historii, mianowicie:

Wykres 2. Temporalne relacje między kluczowymi momentami życia świadka historii $\mathrm{z}$ punktu widzenia prowadzenia rozmowy

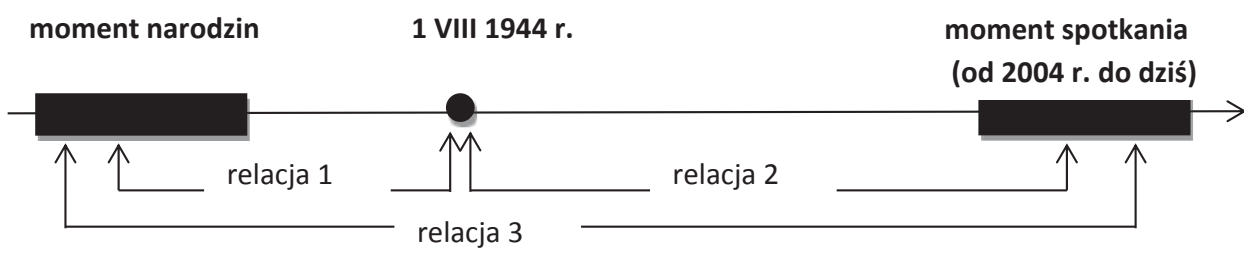

Legenda:

relacja 1 - relacja między momentem narodzin świadka a czasem powstania

relacja 2 - relacja między czasem powstania a momentem spotkania ze świadkiem historii

relacja 3 - relacja między momentem narodzin a momentem spotkania ze świadkiem historii

Źródło: opracowanie własne. 
Pamięć o wydarzeniu będącym tematem rozmowy zależna jest od opisanych wyżej relacji. Im krótsza relacja 1, tym „odpamiętywanie” wydaje się mniej możliwe (dziecko zapamiętuje wydarzenia inaczej niż osoba dorosła, zazwyczaj nie jest to ogląd świadomego uczestnika wydarzeń, ale osoby pamiętającej swoje odczucia czy pewne fragmenty wydarzeń), podobnie dzieje się, gdy dłuższa okazuje się relacja 3, każdy mijający rok bowiem zazwyczaj zaciera obrazy, fakty, konkrety, pozostawiając raczej emocje czy wyobrażenia (z wiekiem pamiętamy jednak mniej lub inaczej).

Dotychczas, opisując zmienne istotne dla spotkania ze świadkiem historii, skupialiśmy się głównie na świadku, warto jednak zauważyć, że równie ważną funkcję pełni osoba prowadząca spotkanie. Jest to kobieta lub mężczyzna i tę zmienną jesteśmy w stanie określić - znamy imię i nazwisko prowadzącego spotkanie. Pozostałe zmienne są odbiorcy nieznane, choć warto pamiętać, że jest to osoba o pewnym kontekście społecznym (wykształcenie, doświadczenie) czy biologicznym (wiek). Zgodnie z założeniami historii mówionej sytuacja spotkania świadka historii z osobą prowadzącą rozmowę stanowi podstawę tworzenia narracji wspomnieniowej, dlatego też $w$ tym akcie komunikacji istotną rolę odgrywa postać pytającego. Według zaleceń zawartych w materiałach dotyczących sposobów badań realizowanych w nurcie historii mówionej osoba przeprowadzająca rozmowę ma być niewidoczna (por. Moyer 1993) - w centrum usytuowany jest świadek historii i jego opowieść. W literaturze przedmiotu często spotyka się określanie tego typu rozmowy mianem wywiadu narracyjnego (por. Kaźmierska 1997). Jego główny cel ujawniany jest przez przydawkę gatunkującą - narracyjny, która zwraca uwagę na swobodny tok wypowiedzi świadka historii, a w efekcie na rezultat, jakim jest uzyskanie relacji o życiu jednostki. Mimo swobody osoby, z którą przeprowadzany jest wywiad narracyjny, ważną rolę w kształtowaniu opowieści odgrywa pytający, co lingwiście wydaje się oczywiste.

Przejdźmy jednak do opisania korpusu, który w naszym odczuciu pozwoli wskazać, w jaki sposób prowadzący spotkanie ze świadkiem historii dba o wypełnienie scenariusza, a zatem prowadzi rozmowę z intencją osiągnięcia założonego w nim celu. Spośród bogatego zbioru rozmów pochodzących z zasobów Archiwum Historii Mówionej do badań wybrano 32 teksty, które ukazują relacje nadawczo-odbiorcze realizowane w trakcie spotkań ze świadkami historii. Kryterium doboru tekstów do analizy była nietożsamość prowadzących rozmowę w poszczególnych interakcjach, dzięki temu wykluczono wpływ stylu indywidualnego (Zdunkiewicz-Jedynak 2008: 19) na wyniki badań. $Z$ kolei w przypadku drugiego uczestnika rozmowy, w celu prowadzenia analiz materiału zróżnicowanego ze względu na parametry socjolingwistyczne, wybrano grupę świadków historii będących w różnym wieku, o różnej płci i o odmiennym statusie uczestnictwa w wydarzeniach.

Ponieważ głównym przedmiotem naszego namysłu w kontekście interesującego nas aktu komunikacji jest pytający, przedmiotem szczegółowego oglądu uczyniłyśmy 1931 aktywności werbalnych osób prowadzących spotkanie z uczestnikami 
powstania warszawskiego. Interesuje nas specyfika tych aktywności oraz wyłaniające się na podstawie ich analizy role, w jakie wchodzi pytający. Jak już wcześniej wspominałyśmy, pierwszoplanową rolę w wypowiedzi przygotowanej w konwencji historii mówionej odgrywa świadek historii, osoba prowadząca spotkanie usuwana jest w cień, stając się na tyle neutralną i niewidoczną, na ile pozwala przebieg rozmowy. Takie są też założenia historyków i socjologów, którzy metodę historii mówionej stosują od lat. Tezę o drugoplanowej roli pytającego i jego „ukrywaniu się” za pytaniami nienacechowanymi jego podmiotowością obala wiedza językoznawcza (por. ustalenia Barbary Bonieckiej (2000) dotyczące pragmatycznej funkcji pytań oraz Urszuli Żydek-Bednarczuk (1994) związane z krokami w rozmowie potocznej).

Założyłyśmy za Jackiem Warchalą $(1991)^{2}$, że struktura klasycznego dialogu składa się z trzech elementów: inicjacji, reakcji i nieobligatoryjnej kody. Śląski lingwista rozmowę traktuje jako „odkrywanie wspólnej "przestrzeni dla słowa«”, a sam tekst, będący jej rezultatem, jest według niego „efektem współprodukcji, [...] która zakłada czynną postawę obu stron dialogu w każdym momencie jego trwania” (ibid.: 38). W przypadku analizowanego materiału - podczas spotkań ze świadkiem historii - owa wymienność, właściwa klasycznej rozmowie, nie występuje, co jest zgodne z zaleceniami i instrukcjami prowadzenia tego typu spotkań. Według wytycznych inicjacje pojawiać się mają tylko po stronie osoby prowadzącej rozmowę; zadaniem świadka historii jest jedynie reagowanie na nie. Dla prowadzącego inne aktywności werbalne, takie jak reagowanie czy podsumowywanie w postaci kody, nie są przewidziane.

Jak już zostało wcześniej nadmienione, proces inicjowania rozmowy ma znaczący wpływ na jej kształt. Tym samym warto zwrócić uwagę na typy inicjacji w sytuacji spotkania ze świadkiem historii. Ogląd materiału badawczego pozwolił nam dostrzec pewne parametry pozwalające wyekscerpować typy inicjacji ${ }^{3}$ istotne $\mathrm{z}$ naszego punktu widzenia, są to mianowicie:

1. Inicjacje otwierające - to pytania wprowadzające nowy temat lub nowy wątek w obrębie poruszanego tematu, np. życia świadka w czasie wojny (poruszane

2 Wedle lingwisty „dialog jako tekst tworzony jest przez łańcuch kolejno po sobie następujących wymian, z których każda może być opisana jako wypadkowa procesu komunikacyjnego" (Warchala 1991: 114). Warto zaznaczyć, że taką wymianę buduje w sytuacji kanonicznej inicjacja i reakcja. Obok przywołanych wyżej wymian proces komunikacyjny w dialogu budują również: „dwaj nadawcy (wyjątkowo jeden) i ich konsytuacja, dalej - dziedzina zaktualizowanych przedmiotów oraz stanów rzeczy, czyli najogólniej pojęty temat rozmowy, także cel rozmowy rozumiany jako intencja nadawcy, aby komunikat odniósł pewien skutek" (ibid.).

3 Kwestia terminologii była przedmiotem naszego głębokiego namysłu i po rozważeniu różnych możliwości doszłyśmy do wniosku, że zaproponowane nazwy będą najodpowiedniejsze. I tak inicjacje uzupełniające i pogłębiające to takie, które prowadzą do uzupełnienia i pogłębienia tematu lub wątku, porządkujące zaś służą uporządkowaniu rozmowy. Mimo swej niejednoznaczności wydają nam się w tym kontekście najlepsze. 
w zakresie tego tematu wątki to np. konspiracja, wybuch powstania itp.), niezależne bezpośrednio od wcześniejszych pytań, np.:

\section{Pytający (P): Gdzie pan był w czasie Powstania? ${ }^{4}$}

Świadek historii (S): W czasie Powstania mieszkałem z rodzicami na ulicy Żabiej 5, na piątym piętrze. Okna wychodziły na Ogród Saski. To jest o tyle ważne, że stamtąd był później olbrzymi ostrzał na ten budynek z Ogrodu Saskiego (APW2).

P: Lato 1939 roku. Czy czuło się napięcie, że będzie wojna? Czy Polacy wierzyli w to, że będzie wojna?

Ś: Tak. Oczywiście. W ostatnich miesiącach było już wyraźne nastawienie, że będzie wojna. Były nawet próbne naloty, żeby nas przyzwyczaić, i straszono nas gazem! (APW4)

P: Jak pan zapamiętał dzień 1 sierpnia? Dzień wybuchu Powstania.

Ś: Nie wiem, czy to potwierdzają fakty, czy nie, o dziesiątej [czy] jedenastej był sygnał syreny. Wyła syrena w Warszawie. Brat był wtedy w domu. Wiem, że strasznie się zdenerwował (APW2).

2. Inicjacje uzupełniające - pytania uzależnione od kontekstu, występują zawsze po inicjacjach otwierających, ich funkcją jest stymulowanie świadka do ujawnienia szczegółów opowiadanych zdarzeń, pominiętych informacji, np.:

\section{P: Urodził się pan na Syberii, a później...}

Ś: W 1921 roku rodzice wrócili do Polski, do Warszawy. Od tej pory mieszkałem stale w Warszawie, aż do pójścia do niewoli, i później po niewoli znowu w Warszawie.

\section{P: Mial pan rodzeństwo?}

Ś: Owszem, miałem siostrę, która umarła w 1932 roku na zapalenie osierdzia, a w Kemerowie zmarło jeszcze moje starsze rodzeństwo, brat i siostra.

\section{P: Rodzice długo przebywali na Syberii?}

S: Od 1912 roku.

P: Za co tata został tam zesłany?

Ś: Trudno mi powiedzieć, o tym się nie mówiło nigdy, a zmyślać nie chcę. Tylko tyle wiem, że był zesłany, że pracował w kopalni [...] (APW3).

3. Inicjacje pogłębiające - także zależne od kontekstu, występują zawsze po pytaniach uzupełniających, ich funkcją jest wydobycie jak najbardziej precyzyjnych i szczegółowych, wręcz drobiazgowych informacji, np.:

4 Wszystkie podkreślenia pochodzą od autorek. 


\section{P: Jak wyglądały lata okupacji? Jak to się stało, że znalazł się pan w Warsza- wie? [inicjacja otwierająca]}

Ś: Musiałem z matką uciekać, ponieważ władze ZPW [...] zostawiły całą dokumentację, która trafiła do rąk niemieckich. [...] Były tam wpisy, co zrobić z powstańcami. Między innymi mój ojciec jest naznaczony do likwidacji.

P: Ojciec był powstańcem wielkopolskim? [inicjacja uzupetniajaca]

Ś: Tak, mój ojciec był powstańcem i dlatego w pierwszej kolejności zginął. Aresztowali go i w dodatku w jakich okolicznościach! Niektórzy Polacy od razu zostali zdrajcami. Otóż ratowało się mienie polskie, które Niemcy w mieszkaniach zapieczętowali. Dokonywano włamań i to, co można było ratować - ratowano. [...] Ojciec nawet nie zdążył być jako powstaniec aresztowany. Został po prostu aresztowany jako zwykły złodziej.

P: Ale później jeszcze wyszło na jaw, że był powstańcem wielkopolskim?

Ś: Dowiedzieli się i potem oczywiście dołożyli mu jeszcze.

P: Ale gdzie został aresztowany i w którym miejscu przebywał?

Ś: Najpierw przebywał na Młyńskiej, a potem gehenna była. [Przeszedł] przez inne więzienia, aż trafił do Mauthausen, gdzie zginął (APW4).

4. Inicjacje porządkujące - mają charakter metatekstowy, wskazują na kierowanie przez prowadzącego przebiegiem rozmowy zgodnie z przewidywanym porządkiem, np.:

Ś: W mieszkaniu pani Haliny Bełkowskiej, jak pamiętam, na Koszykowej, gdzie później była przygotowana gospoda, i to było na Mokotowskiej 39. W jej mieszkaniu prywatnym na pierwszym piętrze. [...] Tam były zbiórki.

P: Zaraz do pracy gospody przejdziemy. Czy będąc już w Warszawie, miały panie kontakt jakikolwiek z tatą, który był u Sowietów? (APW5)

5. Reakcje - aktywności ujawniające podmiotowość, a tym samym subiektywizm pytającego, czyli mówienie o czymś i jednoczesne przekazywanie osobistego wyobrażenia mówiącego. Manifestują się one przez posługiwanie się pewnymi aktami mowy, takimi jak opinie, oceny, sądy, mówienie o uczuciach (Kita 1998: 125-126, 130), np.:

Ś: W Ożarowie była hala fabryczna, betonowa podłoga i słoma. Nas tam rozłożyli. Pamiętam, że ponieważ byłam ze zdrowiem zawsze na bakier i każde zaziębienie zawsze przechorowałam ciężko [...], a tu przyszłam cała przemoczona, [...] więc położyłam się na słomie na betonie, przykryłam się mokrym [płaszczem], przeżegnałam się i powiedziałam: „To już chyba koniec mój. 
Tego to już na pewno nie wytrzymam”. Ale się okazało, że wytrzymałam, nawet kataru nie dostałam.

\section{P: Zahartowała się pani.}

Ś: Tak. Jedno, co [zostało dobre], to chyba właśnie, że się zahartowałam (APW5).

Przeanalizowany materiał składał się z 1931 aktywności werbalnych pytającego, wśród nich najwięcej odnotowano inicjacji pogłębiających - 868, nieco mniej inicjacji uzupełniających - 571, inicjacji otwierających było 389. Poza tym prowadzący spotkania 55 razy posłużyli się inicjacjami porządkującymi, a 133 razy zareagowali na wypowiedź świadka ${ }^{5}$.

Jak zakładamy i jak sugerują instrukcje i poradniki historii mówionej, celem spotkania ze świadkiem historii jest wypełnienie przygotowanego scenariusza. Wobec tego aktywności werbalne pytającego podporządkowane są jego osiągnięciu - takiemu poprowadzeniu rozmowy/wywiadu, by świadek historii opowiedział o wszystkich kwestiach interesujących prowadzącego. Swe cele realizuje on, wchodząc w różne role ${ }^{6}$. Można je zidentyfikować, przyglądając się proporcjom występowania wskazanych powyżej typów aktywności werbalnych. Cechuje je dynamiczność i zmienność - układają się one różnie zarówno w poszczególnych spotkaniach, jak i we fragmentach tej samej rozmowy. W badanym materiale dało się zauważyć jednak pewne tendencje. Pierwszą z nich jest dominacja inicjacji otwierających, często układających się w niezależne od siebie ciągi, przy sporadycznym występowaniu inicjacji uzupełniających i porządkujących. Inicjacje pogłębiające i reakcje wówczas nie występują. W spotkaniach z tak układającymi się wymianami prowadzący wywiad nie wchodzi w interakcję ze świadkiem lub robi to niezwykle rzadko, powstrzymuje się także od subiektywnych reakcji. Koncentruje się głównie na wypełnieniu zakładanego scenariusza - wchodzi w rolę, którą chcemy nazwać rolą dziennikarza.

W kolejnej grupie wywiadów można dostrzec tendencję do sporadycznego wykorzystywania inicjacji otwierających i pogłębiających, rzadko występują także inicjacje porządkujące i reakcje. Te ostatnie pojawiają się zazwyczaj wtedy, gdy pytający chce zbudować wspólnotę ze świadkiem historii, najczęściej wspólnotę wiedzy i doświadczeń. Dominującą pozycję zajmują natomiast inicjacje uzupełniające. W takiej sytuacji pytający przypomina aktywnego słuchacza, który nie skupia się wyłącznie na wypełnieniu scenariusza, a rozmowa toczy się płynnie, ponieważ kolejno

5 Niektóre $\mathrm{z}$ aktywności werbalnych zostały przyporządkowane do dwu kategorii.

6 Inspiracją dla zaproponowanej typologii stały się uwagi badaczy o roli, w jaką każdorazowo wchodzi moderator w klasycznym wywiadzie. Wśród naukowych refleksji na ten temat wymienić można m.in. wprowadzony przez Zbigniewa Bauera (2008) podział ról na pośrednika-pomocnika, partnera-ucznia, partnera-eksperta czy partnera-reprezentanta oraz klasyfikację ról dziennikarskich autorstwa Moniki Worsowicz (2006), na podstawie której badaczka wskazuje rolę ucznia, petenta, lustra, wielbiciela, prokuratora, eksperta i partnera. 
zadawane pytania nawiązują do treści bądź wypływają z treści opowieści świadka. Pytający przyjmuje wówczas rolę przyjaciela.

Ostatnią zaobserwowaną tendencję wyróżnia dominacja inicjacji uzupełniających i duża liczba inicjacji pogłębiających. Inicjacje otwierające stanowią najmniejszą grupę wśród jednostek pytających. Zadający pytania częściej porządkuje przebieg spotkania i reaguje na wypowiedź świadka. Reakcje dotyczą zazwyczaj sytuacji, gdy prowadzący konfrontuje wiedzę przekazywaną przez świadka $\mathrm{z}$ wiedzą własną. Inicjacje porządkujące $\mathrm{w}$ porównaniu $\mathrm{z}$ innymi typami inicjacji mają jednak charakter sporadyczny, w nieco większej liczbie w stosunku do inicjacji pytających występują reakcje. Taką strategię prowadzenia spotkania obiera badacz. W głównej mierze zależy mu na wydobyciu z pamięci świadka jak największej liczby informacji, pogłębianiu i weryfikowaniu przekazywanej wiedzy. Nie zadowala go pobieżne nakreślenie obrazu czasów minionych, to on decyduje o stopniu szczegółowości przywoływanej opowieści i tych jej fragmentów, które mają zostać ukazane w sposób pogłębiony ${ }^{7}$.

Przypomnijmy, że wyróżnione typy jednostek dialogowych występują w różnych proporcjach w obrębie jednego wywiadu. Oznacza to, że pytający podczas jednego spotkania wchodzi w różne role, należy je zatem traktować nie jako stałe, lecz wymienne. Wyjątek stanowi tu rola dziennikarza - jest jedyną, która występuje samodzielnie $w$ ramach jednego spotkania. Interakcje werbalne, w których prowadzący wpisuje się wyłącznie w rolę dziennikarza, są właściwe dla bardzo krótkich spotkań ze świadkami historii. Warto w tym miejscu zwrócić uwagę na jeszcze jeden parametr, którym jest właśnie długość spotkań. Obserwujemy wywiady krótkie - najkrótsze zawierają od 6 do 25 aktywności werbalnych prowadzącego - które stanowią 30,3\% wszystkich zbadanych zapisów. W wywiadach najdłuższych prowadzący podejmują aktywność od 117 do 187 razy (18,18\%). Pozostałe, mieszczące się w zbadanej próbie w przedziale od 39 do 94 (51,52\%), uznajemy za spotkania optymalne. Skłania nas do wysnucia takiego wniosku ich frekwencja - stanowią najliczniejszą grupę. $\mathrm{Z}$ analizy wynika także, że niezależnie od długości wywiadu każdy z nich realizuje scenariusz spotkania, długość wywiadu nie ma zatem wpływu na wypełnienie obowiązującego planu interakcji.

7 Odejście od realizacji scenariusza spotkania i wejście w poszczególne role wiązać można z procesem współkreowania pożądanego obrazu przeszłości lub negocjowania wyobrażeń o czasach minionych, a więc z relacjami władzy nad dyskursem narracji wspomnieniowej. Szczegółowo o problemie nieprzezroczystości prowadzącego spotkanie ze świadkiem historii piszemy w artykule Władza nad dyskursem narracji wspomnieniowych. Przypadek Archiwum Historii Mówionej (Ciesek-Ślizowska, Duda, Sujkowska-Sobisz, w druku). 


\section{Podsumowanie}

Podsumowując, szczegółowa, oparta na danych ilościowych i jakościowych analiza zebranego materiału dowodzi, że pomimo zaleceń historii mówionej i wynikającego z nich obowiązku przekazania roli kreowania narracji wspomnieniowej świadkowi historii to pytający jest podmiotem, który determinuje kształt opowieści. Tym samym autentyczność, która stanowi podstawę zainteresowania przeszłością w wymiarze jednostkowych wspomnień, może zostać zakwestionowana ${ }^{8}$, zwłaszcza w kontekście konieczności zrealizowania scenariusza spotkania bez względu na długość interakcji i role, które ogrywa teoretycznie drugoplanowy aktor spotkania. Okazuje się bowiem, że obraz rzeczywistości, jaki wyłania się z unikalnych wspomnień, jest profilowany nie przez wybory samego podmiotu - świadka historii - ale przez cele, jakie przyświecają osobie przeprowadzającej wywiad. Pytający działa według określonych wytycznych, ma także własne intencje, które ujawnia w trakcie prowadzenia spotkania. Przez to władza nad narracją wspomnieniową jest po jego stronie ${ }^{9}$.

\section{Literatura}

Bauer Z., 2008, Wywiad. Gatunek i metoda, [w:] idem, Dziennikarstwo iświat mediów, red. E. Chudziński, Kraków, s. 333-334.

Boniecka B., 2000, Struktura i funkcje pytań w języku polskim, Lublin.

Ciesek-Ślizowska B., Duda B., Sujkowska-Sobisz K., w druku, Władza nad dyskursem narracji wspomnieniowych. Przypadek Archiwum Historii Mówionej.

Grele R.J., 1996, Directions for Oral History in the United States, [w:] D.K. Dunaway, W.K. Baum (red.), Oral History. An Interdisciplinary Anthology, Walnut Creek, s. 39-62.

Havelock E.A., 2006, Muza uczy się pisać. Rozważania o oralności i piśmienności w kulturze Zachodu, tłum. P. Majewski, Warszawa.

KAźMIERSKA K., 1997, Wywiad narracyjny - technika i narzędzia analityczne, [w:] M. Czyżewski, A. Piotrowski, A. Rokuszewska-Pawełek (red.), Biografia a tożsamość narodowa, Łódź, s. 35-44.

Kita M., 1998, Wywiad prasowy. Jezzyk, gatunek, interakcja, Katowice.

Moyer J., 1993, Step-by-Step Guide to Oral History, [on-line:] dohistory.org/on_your_own/ toolkit/oralHistory.html.

ONG W., 1992, Oralność i piśmienność. Słowo poddane technologii, tłum. J. Japola, Lublin.

PAмIįć: W. Czachur (red.), Pamięć w ujęciu lingwistycznym. Zagadnienia teoretyczne i metodyczne, Warszawa 2018, [on-line:] https://doi.org/10.31338/uw.9788323530077.

8 Kwestionowanie autentyczności narracji wspomnieniowej związane $\mathrm{z}$ odejściem od scenariusza można rozpatrywać jako rezultat odświeżania pamięci (kiedy prowadzący spotkanie próbuje pomóc świadkowi w przywołaniu obrazów przeszłości) bądź też manipulacji. Dokładniejsze rozważenie tego problemu wymaga jednak osobnego opracowania.

9 Szczegółowo tym kwestiom przyglądamy się w opracowaniu Władza nad dyskursem narracji wspomnieniowych (ibid.). 
Pamięć, etyka: E. Domańska (red.), Pamięć, etyka i historia. Anglo-amerykańska teoria historiografii lat dziewięćdziesiątych (antologia przekładów), Poznań 2002.

Pomian K., 2006, Historia - nauka wobec pamięci, Lublin.

Stolarz A., 2012, Historia mówiona w warsztacie historyka mentalności, „Pamięć i Sprawiedliwość" nr 2 (20), s. 103-114.

WARChala J., 1991, Dialog potoczny a tekst, Katowice.

Worsowicz M., 2006, Gatunki prasowe. Poradnik dla uczniów i nie tylko..., Łódź.

ZdunKieWICZ-JedynaK D., 2008, Wykłady ze stylistyki, Warszawa.

Żydek-Bednarczuk U., 1994, Struktura tekstu rozmowy potocznej, Katowice.

\section{Źródła}

APW1: Archiwum Historii Mówionej (Muzeum Powstania Warszawskiego) - strona główna, [on-line:] http://www.1944.pl/.

APW2: Wywiad z W. Białowasem przeprowadzony przez M. Rafalska-Dubek, Warszawa, 21 VIII 2013 r., Archiwum Historii Mówionej, [on-line:] http://www.1944.pl/archiwumhistorii-mowionej/wojciech-bialowas,3193.html.

APW3: Wywiad z A. Bienieszewskim przeprowadzony przez M. Bramę, Warszawa $30 \mathrm{~V}$ 2006 r., Archiwum Historii Mówionej, [on-line:] http://www.1944.pl/archiwum-historiimowionej/antoni-bieniaszewski,762.html.

APW4: Wywiad z A. Bittnerem przeprowadzony przez M. Bramę, Poznań, 16 V 2006 r., Archiwum Historii Mówionej, [on-line:] http://www.1944.pl/archiwum-historii-mowionej/ antoni-bittner,1145.html.

APW5: Wywiad z K. Bień przeprowadzony przez A. Seta, Warszawa, 18 II 2010 r., Archiwum Historii Mówionej, [on-line:] http://www.1944.pl/archiwum-historii-mowionej/krysty na-bien,2127.html.

W1: Fundacja Ośrodka KARTA, [on-line:] http://karta.org.pl/.

W2: Fundacja Kobieca eFKa, [on-line:] http://efka.org.pl/.

W3: Ośrodek „Pogranicze - sztuk, kultur, narodów”, [on-line:] http://pogranicze.sejny.pl/.

W4: Ośrodek „Brama Grodzka - Teatr NN”, [on-line:] http://teatrnn.pl/.

W5: Ośrodek Pamięć i Przyszłość, [on-line:] http://www.zajezdnia.org/.

\section{On the (In)Visibility of the Leader in a Meeting with a Witness of History. A Preliminary Typology of Roles that Initiate Narrative Interviews Summary}

The paper reflects on sender-recipient relations characteristic for the participants of a narrative interview with a witness of history. The research material comprises 1931 verbal activities, collected in the Archive of Oral History of The Warsaw Rising Museum, of people who conducted 32 meetings with participants of the Warsaw Uprising in 1944. The application of the interactive concept of text allowed us to create a preliminary typology of the activities of meeting leaders, viz. to identify four types of initiation: the opening, the complementary, the deepening and ordering, and the reactive one. Further analyses led to the identification of roles taken on by people who conduct meetings with witnesses of history, which we named the journalist, the researcher, and the friend. 